\title{
REALISM AND TYPOLOGY IN CHARLOTTE M. YONGE'S THE HEIR OF REDCLYFFE
}

\author{
By Gavin Budge
}

\section{Charlotte Yonge's Religious Realism}

RECENT ATTEMPTS at a critical recuperation of the fiction of Charlotte M. Yonge have largely sidestepped the issue of her work's commitment to a religious perspective. June Sturrock's brief 1995 monograph, "Heaven and Home": Charlotte M. Yonge's Domestic Fiction and the Victorian Debate over Women, is focused on the way in which Yonge's Tractarian beliefs provided a framework within which a conservative feminist account of an independent social role for women could be articulated, but takes those beliefs themselves as givens. Catherine Sandbach-Dahlström's more substantial 1984 study, Be Good Sweet Maid: Charlotte Yonge's Domestic Fiction: A Study in Dogmatic Purpose and Fictional Form, whilst noting a relationship between apparent changes in Yonge's religious beliefs and differences in the form of her novels, is characterized by a formalist mode of interpretation which tends to bracket off the question of how Yonge presents religious belief in her novels from any wider context in Victorian religious thought.

In this paper, I would like to examine the relationship between Yonge's novelistic presentation of religious belief and prevailing critical characterizations of realism in the novel. Historians of the novel such as Ian Watt, following Lukács's pronouncement that "the novel ... is the epic of a world forsaken by God" (Watt 1957, 84) have tended to portray the novel form as inescapably committed to a secular view of the world. Charlotte Yonge's novels present something of a problem for this characterization of the novel form, since they possess all the features Watt identifies with what he calls "formal realism" (Watt 1957, 83-85) - to an extent that led Victorian critics to complain about her excessive and undiscriminating realism (Hutton 214) - but combined with a religious perspective that extends far beyond superficial pieties, informing minute details of plot and characterization.

Of course, it is possible for a modern critic to find tensions and contradictions between Yonge's religious views and her realist literary method, a tactic which was already being pursued by her contemporary R. H. Hutton in his impressively serious 1861 review of her work. As is noted by Catherine Sandbach-Dahlström (18-20), who follows Hutton's line of interpretation, however, the extent to which a reader finds Yonge's realism and her Tractarianism in conflict largely depends on the differences between that reader's perspective and Yonge's own - it is not the product of incoherence in Yonge's work itself. No less a 
figure than Henry James expressed his admiration for the artistry with which Yonge remains in command of her materials (Wolff 135).

The fact of Yonge's astonishing popularity might also lead us to question the adequacy of the Wattsian secularist characterization of novel form. The Heir of Redclyffe was one of the best-selling novels of the nineteenth century, appealing to an audience which went well beyond Yonge's fellow Tractarians, and Yonge remained popular with Victorian readers throughout her prolific forty-year writing career (Yonge 1997, vii). Her novels went on being reprinted into the 1920s, and enjoyed a general revival of interest in the 1940s (Battiscombe 165-67). It is not possible to dismiss Yonge's work as possessing interest merely for a narrow group of sectarians.

It is part of the object of this paper to suggest that Yonge's religious position as a Tractarian is not in conflict with the artistic seriousness and self-awareness of her writing. This argument, of course, runs counter to much received critical opinion about Victorian "moralizing," which is normally seen as detracting from, or damaging to, artistic achievement. However, to assert that expressions of religious commitment are necessarily inimical to a work's status as art is to make an a priori assumption that the domain of aesthetics necessarily excludes practical questions of morality (cf. Budge, passim). This claim is characteristic of artistic modernism, but is, of course, one that most Victorians would whole-heartedly have rejected, as the example of Ruskin shows.

The assumption that artistically responsible realist writing necessarily tends in the direction of religious and moral skepticism (or at least, lack of identifiable commitment to a particular religious or moral position) is one that underpins the argument of George Levine's classic 1981 study, The Realistic Imagination, a work I will discuss in some detail because it continues to be highly influential and represents, along with Watt's The Rise of the Novel, a widely held view of nineteenth-century realism that leaves no place for Yonge's oeuvre. Levine's account of the development of nineteenth-century realism relies identifiably on a historical view of modernity as a process of general secularization. For Levine, the "characteristic morality" of Victorian realism is "a George Eliot-like dissolution of easy moral categories" (180), in which a "metaphysical sanction" is replaced by a "humanist sanction" (11).

From such a secularist viewpoint, Yonge's commitment to Tractarianism would be merely quaint, a failure to move with the times that must call her ability to achieve a truly realist mode of writing into question. Levine's choice of George Eliot as the paradigmatic nineteenthcentury realist is of course an expression of the implicit secularist teleology that underlies his narrative of the novel's development. Just how far Yonge was from admitting any necessary identity between realist narrative and secularism can be seen from her comments on George Eliot in whom she obviously detected a subtle perversion of the realist impulse: she found that Middlemarch left "a sense of hollowness. The ideal gradually became lowered, the imagination tarnished, the purpose stronger perhaps but more perverted," an effect which she attributed to the "blighting and poisoning influence" of G. H. Lewes (qtd. in Tillotson 69)Levine, by contrast, gives great prominence to the role of Lewes in the gestation of the novel. The relationship between Eliot and Lewes is thus seen by Yonge in terms which echo her description of the mental perversion Laura undergoes in her relationship with Philip in The Heir of Redclyffe, which I discuss later in this paper. Yonge sums up her view of George Eliot in terms which would definitely be unacceptable to the secularist critic: for her, George Eliot is like one of Satan's instruments "doing all the more harm by their practice of outward 
virtues" - virtues which would include those of the realist novelist, since Yonge rated Eliot's powers of "representation" very highly.

Yonge's religious perspective on realism, however, is not as isolated as Levine's secularist assumptions may make it appear. Levine's account downplays an alternative British intellectual tradition that I would argue is as central to nineteenth-century realism as the skeptical one he foregrounds. A symptom of this is the way Levine uses Richard Whately's 1821 review of Austen throughout The Realistic Imagination to represent a straw man position characterized by "massive confidence" in reality which the "empiricism and secularity" Levine attributes to realist novelists works to undermine (1981, 38). Whately comes across in Levine's account as a naive thinker who unconsciously contradicts himself when he praises Austen's "vivid distinctness of description," (39) an emphasis which in Levine's interpretation undoes Whately's "religious rationalism," (38) since its privileging of detail runs counter to his moralistic insistence that the "norms" of poetic justice "are the real reality, discernible - in an older philosophical tradition of realism - behind the confusions of mere particularities." Austen, in contrast, despite being a dean's daughter, approaches toward "typicality," in Levine's view, through an essentially secular "rich and mature acceptance of the culture's ideals."

Levine does not take Whately seriously as a thinker. But at the time he wrote the review of Austen, Whately was at Oxford, and a major influence on Newman and other Tractarians. It would be hard indeed to find a nineteenth-century writer less likely to be guilty of intellectual carelessness than Whately, who later became the famous author of a much-reprinted treatise on logic to which Newman himself contributed material (Middleton 40-47), and which John Stuart Mill set himself to discredit in his A System of Logic.

Levine's mistake in finding a contradiction between Whately's praise of Austen's detail and his claim that the novel should illuminate the providential justice at work in the world becomes apparent if we compare Whately's position to that of Ruskin, for whom, of course, it is precisely realistic "detail" that has the potential to reveal God's providence at work in the natural world (Ruskin 2: 60-61). Levine treats Ruskin somewhat more respectfully, and even notes the connection between Whately's and Ruskin's worldview (Levine 1981, 51), remarking that Ruskin believed "that the visible world will answer to Whately's sort of dream of order." Levine later concedes that Ruskin's position reveals "certain crucial epistemological problems involved in the attempt to represent reality truthfully," problems which he sees Lewes' Problems of Life and Mind as an attempt to work through (257). In refusing to take Whately's "religious rationalism" seriously (38), Levine is dismissing problems, which later turn out to be central to his analysis of Middlemarch.

Levine's disregard of Whately damages the coherence of his argument. Consistently, Whately cannot be dismissed without also waiving the relevance of Ruskin, since both are representatives of the so-called "Common Sense" school of philosophy, which was massively influential in Britain during the first seventy years of the nineteenth century. Common Sense philosophy constituted an alternative to Hume's associationism (which was only revived towards the end of the nineteenth century); it is an important omission in Levine's argument because it represented an alternative kind of empiricist position, one which Common Sense philosophers themselves identified with Bacon (Reid 202). Much of Levine's characterization of realism's "faith that the realist writer's exploration will reveal a comprehensible world," its "disrupting [of] conventions of moral judgement" and even its "self-consciousness about the difficulties of the arguments in favor of common 
sense" recalls the Common Sense philosophical position (Levine 1981, 18, 20, 19); this is perhaps unsurprising, because Common Sense philosophy was the only generally current defense of "realism" in a philosophical sense for much of the nineteenth century in Britain. ${ }^{1}$

For Whately, the kind of conflict between detail and moral normativity, which Levine diagnoses, does not really exist, because from the Common Sense philosophical perspective no perception is pre-linguistic. Levine seems to want to derive the moral normativity of Austen's narrative - what he calls her "typicality" (Levine 1981, 38) - from the way in which her language use embodies the moral standards of her community, which is why he invokes her "rich and mature acceptance of the culture's ideals." Common Sense philosophy, however, regards perception itself as essentially a linguistic process, in which divinely instituted signs are actively interpreted by the perceiving mind (Reid 134-35, 201). Whately, then, like Ruskin, regards moral norms as being inherent in our perceptions of nature for essentially the same reasons that Levine thinks moral norms are inherent in Austen's narrative: language always implies evaluative norms, and for Whately and Ruskin perception is itself a language. Austen's "vivid distinctness of description" (Levine 1981, 39) and her use of poetic justice are thus both equally for Whately an indication of her faithfulness to the natural moral order of things: one does not contradict the other because religious values themselves are simply a continuation of the supernatural and semiotic dimension which is inherent in our experience of nature.

I have stressed the significance of Levine's refusal to take Whately's reaction to Austen seriously partly because his position is very close to that of Charlotte Yonge herself; indeed, there is some evidence in The Heir of Redclyffe that she had read his work on logic. ${ }^{2}$ Yonge was strongly influenced by Austen, particularly in early novels such as Abbeychurch, a fact which in so self-conscious a writer as I intend to show Yonge was must suggest that there is more "typicality" in Austen's work than Levine is prepared to give her credit for (Levine 1981, 38). It might be possible to find the infusion of realistic detail with typological significance which, as this paper will suggest, is so characteristic of The Heir of Redclyffe, also in Austen's work, though this would probably require a more detailed study of Austen's intellectual milieu than has so far been undertaken. ${ }^{3}$

Levine overlooks the Common Sense philosophical tradition because his conception of "empiricism" is dominated by J. S. Mill. ${ }^{4}$ Before Mill, however, philosophical associationism of the sort Levine identifies with "empiricism," far from being regarded as friendly to realism, was widely thought to be potentially in conflict with it. Hume's associationism, after all, had led him to the claim that it was impossible to arrive at rationally justifiable knowledge of an external world. This is reflected in the way nineteenth-century realists, Yonge among them as we shall see, often understood a habitual state of association as constituting a pathological alienation from reality - one example is Amelia's worshipping of the dead George Osborne and undervaluing of Dobbin in Vanity Fair.

An alternative to Levine's somewhat one-sided presentation of nineteenth-century realism in terms of Mill's associationist empiricism can be found in Edwin M. Eigner's interesting 1978 study, The Metaphysical Novel in England and America. Eigner's description of the techniques of what he identifies as the English and American Bildungsroman has many points of contact with Yonge's novelistic techniques; he emphasizes, for instance, the use of paired characters to explore contrasting paths of development (68-84) which is such a prominent feature of Yonge's treatment of the characters of Guy and Philip in The Heir 
of Redclyffe. Eigner presents his school of "metaphysical novelists" (centered around the figure of Edward Bulwer Lytton) as an alternative to the realist tradition, a characterization which is echoed by Levine's strikingly hostile comment that "romance forms" embody "the secret lust of the spirit to impose itself on the world" which realism must resist (1981, 15). The rigid opposition that Levine wants to enforce between metaphysically orientated "romance" and essentially secularist realism, however, does not seem justified when applied to nineteenth-century fiction of the period 1800-70. Eigner himself makes a convincing case for including Charles Dickens, classed by most critics as a realist, among his "metaphysical novelists," and suggests that even novelists such as George Eliot and Thomas Hardy switch into a "metaphysical" mode at points in their otherwise realist novels (227). Even William Shakespeare Thackeray, who is something of a hero in Levine's account of realism, could be seen as employing what Eigner identifies as the essentially "metaphysical" device of pairs of contrasting characters: this is obviously true of Amelia Sedley and Becky Sharp in Vanity Fair, but also of the way in which George Osborne and Rawdon Crawley can be seen as representing alternative moral paths to that of Dobbin.

The unsatisfactory nature of Levine's rigid demarcation between realism and "romance" is suggested by Jennifer Green-Lewis (72), who describes Levine's attempt to argue that the two are absolutely distinct as "cultural mythmaking":

The "metaphysical novel" ... may ... defy its own presumed obsession with "the why of reality" and shift its attention to the consideration of a "materialistic world view," because of the necessity of exposing the consequences of that world view, "so that metaphysics, which the positivists had banned from philosophy, might be restored as a legitimate province for human inquiry." In other words, the metaphysical novel, to use Eigner's term, or romance, to use mine, for the sake of disproving realism is as likely to engage with its issues as it is to eschew them.

This propensity raises a question that may appear to bring romance closer to the province of realism, for can we really say that a work "about" realism is distinctively different from a work "of" realism? Both kinds of works address the same questions, thereby verifying the centrality and significance of the questions. (32)

I want to suggest in this paper that the religious orientation of Yonge's writing leads her to question the nature of realism in a way that makes her work just as epistemologically selfconscious as any of the writers Levine studies in The Realistic Imagination. As Green-Lewis argues, there can be no justification for excluding such metaphysically oriented testing of the limits of realism from the category of realism itself, particularly since Levine wants to include this kind of reflexivity in his definition of realism.

As Harry E. Shaw suggests, the work of Levine and Watt is not only of historical importance, but continues to underpin much contemporary writing on the theory of realism, even writing with whose theoretical allegiances Levine and Watt would have little sympathy (71-72). The significance of The Realistic Imagination lies in the way it rearticulates Liberal Secularist assumptions, which can seem somewhat simplified and reductive in the writing of Ian Watt, in terms of a fundamental anxiety about the "monstrousness" of a material world which the individual consciousness can never, ultimately, comprehend, an anxiety which has resonated with recent critical interest in the Gothic. The paradigm, which Levine so compellingly articulates has only seriously begun to be called into question in critical work of the last three years, and it, is my hope that the present essay may supply a historical dimension to this rethinking of the critical paradigm of "realism." 


\section{Typology and Tractarianism in Yonge's Fiction}

CHRIS BROOKS DEVELOPS Eigner's category of the "metaphysical novel" in his 1984 study Signs for the Times: Symbolic Realism in the Mid-Victorian World in which, in the course of a discussion of Thomas Carlyle (another Victorian thinker who has recently been shown to have been significantly influenced by Common Sense philosophy) he draws attention to the centrality of typology to an understanding of realism (14). Brooks's wide-ranging study applies this idea of a typological realist mode (what he calls "symbolic realism") to painting and architecture as well as the novel, but in this paper I propose to confine myself to an exploration of the typological dimensions of Yonge's realist narrative, although I think Brooks's extension of the concept is amply justified by the influence of Common Sense philosophy on nineteenth-century aesthetic thinking in general. ${ }^{6}$

The kind of link I am proposing between realism and typology in Yonge can be seen very clearly in Pre-Raphaelite painting, where the realist detail of, for example, Holman Hunt's "The Light of the World" was given a quite elaborate allegorical explanation by contemporary critics (cf. Stephens 24-31). This understanding of realist detail in a typological light was given theoretical justification by John Ruskin. In Modern Painters Ruskin makes it clear that detail in painting is to be valued for its typological relationship to God's work in Creation: pictorial detail reveals a loving attention on the part of the painter which indicates the infinite detail (and infinite loving attention) to be found in Nature (2: 60-61).

Although modern commentators have tended to separate the Ruskinian interest in landscape from the kind of narrativizing interpretation of pictorial detail which Victorian commentary on "The Light of the World" exemplifies (cf. Borzello 34-36), in fact these two tendencies are intimately linked in Ruskin's work, and, I would suggest, in Victorian culture more generally. Ruskin himself suggested that the hallucinatory vividness of detail in Pre-Raphaelite painting should be regarded as testimony to the moral strenuousness of its practitioners (12: 330-32, 334), and shows himself quite capable of narrativizing and moralistic interpretation even of natural details, such as light, in the early books of Modern Painters (4: 77-84) What connects this narrativization of painting with the theological argument from design underlying much of Ruskin's writing on landscape is the assumption that the visible world is a collection of signs whose intelligibility depends fundamentally on the interpretative activity of the perceiver: a picture for Ruskin is not merely a colored surface, but requires to be made sense of, because the material world is, regarded in itself, a fundamentally unintelligible mass of mere sensations.

In a more popular context, similar tendencies towards a typological interpretation of pictorial realism can be found in the catalogue entries written by the organizers of the 1880s Whitechapel Exhibitions, Samuel and Henrietta Barnett, and their helpers. Though these entries have been dismissed by some modern critics as mere "moralizing," (Borzello 34) the Barnetts's interest in landscapes shows that their understanding of the moral influence of painting extends beyond simple narrative pictures. The Barnetts's and Ruskin's preoccupation with the social function of art, makes the connection in their thought between realism and typology strikingly similar to the concerns of Yonge's religiously inflected domestic realism (see Budge, passim).

Given the importance of typology in Victorian culture generally, it is striking that existing criticism makes little or no attempt to explain why there was such an upsurge in typological modes of writing in the first half of the nineteenth century. Paul J. Korshin makes clear that 
typology in the context of Biblical interpretation or allusion flourished during much of the eighteenth century, after a lull at the century's beginning, but that the proliferation of "natural typology," of the kind adumbrated by Wordsworth's use of apocalyptic language in the Simplon Pass episode of The Prelude, is a phenomenon specific to the early nineteenth century (373). As G. B. Tennyson argues, the ascription in Landow's Victorian Types, Victorian Shadows of typology's renewed importance simply to the influence of Evangelicalism is inadequate: the centrality of typological thinking to the Tractarian position shows that it must have a broader cultural source than "Evangelical sectarianism" (34). A similar argument might be made about Herbert L. Süssman's Fact into Figure, which is even more summary in its discussion of the reasons for typology's renewed popularity in nineteenth-century art. Unfortunately, Tennyson does not go beyond detailing the use the Tractarians made of typology: he shows that Keble was referring to "types" in the context of poetic theory as early as 1814 , but gives no reason for the sudden surge in intellectual popularity of typological modes of thinking during the early nineteenth century.

One obvious correlative of the renewed interest in typology is the Romantic Movement. Hilary Fraser makes a connection between the role of typology in Tractarian thought and Coleridge's notion of the symbol (15). But this again cannot constitute an adequate explanation for the importance typology took on in the early nineteenth century: in 1814, the date of publication of Keble's first essay linking poetry and theological "types" ("Sacred Poetry"), Coleridge had yet to publish most of the writings for which he is best known today, and what he had published had only achieved extremely limited circulation. One of Landow's major sources for nineteenth-century thinking about typology, Thomas Hartwell Horne's An Introduction to the Critical Study and Knowledge of the Holy Scriptures, which he describes as "standard reading for British Divinity students" (Landow 1980, 22), was first published in 1818 , only three years after publication of the Biographia Literaria. To suggest that Horne's sympathetic treatment of typological interpretation reflects the influence of Coleridge would be to assume an improbably rapid assimilation of an avant-garde thinker into the theological mainstream.

The typological worldview of the early Victorians, I would like to suggest, is constituted by a confluence of philosophy and theology within the thought of the period. This philosophical theology is not, however, the German Idealist influenced Higher Criticism which became important later in the nineteenth century: the orthodox Thomas Hartwell Horne, for example, roundly rejects the demystifying German school of interpretation represented by Bauer and his followers (499). If one looks at the almost entirely British theological and interpretative sources referenced by Horne, such as Bishop Lowth's Lectures on the Poetry of the Hebrews, they belong largely to the second half of the eighteenth century, and it is to writings of this period, and their influence upon the Tractarians, that I would suggest we must look to find an explanation for the Victorian interest in typology, and the typological strain in Charlotte Yonge's narrative technique.

Horne himself offers a justification for the "spiritual interpretation" of the Biblical text that is typology in the following terms:

\footnotetext{
All our ideas are admitted through the medium of the senses, and consequently refer in the first place to external objects: but no sooner are we convinced that we possess an immaterial soul or spirit, than we find occasion for other terms, or, for want of these, another application of the same terms to a different class of objects; and hence arises the necessity of resorting to figurative and spiritual
} 
interpretation. Now, the object of revelation being to make known things which "eye hath not seen nor ear heard, nor have entered into the heart of man to conceive," it seems hardly possible that the human mind should be capable of apprehending them, but through the medium of figurative language or mystical representations. (496)

Horne is arguing that the legitimacy of typological interpretation rests on the same basis as that of any kind of language we use to talk about the immaterial realm of mind. Since all our ideas are material, in that they come to us through the senses, when we want to talk about the mind (which Horne assumes is radically non-material) we are forced to invent metaphorical applications of our ideas in order to convey our meaning. Since the Bible is a divine revelation of that which transcends the material world, typological interpretation of it must be legitimate, since it is only by means of such figurative applications that Revelation could be conveyed in human language at all.

It is no coincidence that Horne here virtually in the same breath justifies typological interpretation along with all metaphorical uses of language (including, of course, poetry). Horne is deftly summarizing over a century of post-Lockean theological debate about the status of Biblical language. Early eighteenth-century freethinkers such as John Toland (3135) and Anthony Collins (91-92) had invoked Locke's hostility towards metaphor in the Essay Concerning Human Understanding, in order to argue for the redundancy of Biblical revelation itself. If, as Locke had argued, metaphor cannot convey any meaning which goes beyond the ideas we receive through the senses, then presumably, Toland and Collins claim, the Bible cannot be understood to convey any religious truth which is not already available to us through the senses. Collins in particular attacks New Testament typological interpretation of Old Testament prophecy as an intellectually illegitimate and "mystical" use of language (97-99). ${ }^{7}$

Religious orthodoxy, then, is intimately bound up with the defense of the intellectual validity of metaphor, in which Horne engages in the passage I have quoted. In this respect, Horne's argument reflects half a century of Anglican defenses of metaphor as producing a kind of knowledge which is not available to the senses, defenses which include Lowth's Lectures on the Poetry of the Hebrews, Burke's Philosophical Inquiry into the Origin of our Ideas of the Sublime and Beautiful, and Butler's Analogy of Religion. But this is only half the picture, since these defenses of the validity of metaphorical language do not address the Lockean philosophical basis of the freethinkers' advocacy of Natural Religion.

As we have noted, a radical dualism stands behind Horne's defense of typological interpretation. The mind for Horne is essentially "immaterial," so that language, which derives from the material realm of ideas, can only be made to refer to the mental realm by the tropological interpretation to which the mind subjects it. Furthermore, Horne implies, we can only arrive at a knowledge of the immateriality of the mind through a fundamental spiritual intuition: we can be "convinced" of this immateriality, but obviously not through the agency of the material world, since this would be a contradiction in terms.

Landow draws attention to the presence of this mind/body dualism in Victorian typological thought generally $(1980,22)$, but fails to root it in anything specific to the early nineteenth-century intellectual context. I would like to suggest a more definite philosophical source for the Victorian typological worldview in the Scottish Common Sense School of philosophy, whose influence in Britain was at its height in the early decades of the nineteenth century. 
In Yonge's case, the typological dimension of her novelistic realism reflects her close association with the Oxford Movement. As has been suggested by M. H. Abrams (144148) and Stephen Prickett (91-119), the aesthetic position which one of its leading figures, John Keble, puts forward in Tract 89 ("On the Mysticism Attributed to the Early Fathers of the Church") and in his Lectures on Poetry, can be seen as a rewriting of Wordsworth's theory of poetry in religious terms. I will be arguing that this Tractarian version of Romantic poetics informs Yonge's novels in a way that allows her to combine domestic realism with a transcendent dimension of religious typology.

In Keble's view, the analogies which the Wordsworthian poet finds between Nature and his own mind are ultimately justified because Nature itself is an expression of the Divine Mind. Even though the sympathy between Nature and the mind described by Wordsworth is in itself a kind of fiction, for Keble it can nevertheless be said to be true insofar as the relationship between poet and Nature is regarded in a typological light, as an analogy of the mind's relationship to God. Keble suggests that the metaphorical language used by the Wordsworthian poet about Nature has a claim to be regarded as possessing the status of truth inasmuch as it is founded on the divinely inspired language of Biblical revelation (Keble 1839-43, 167).

Keble is interested in Wordsworth's realist poetics not only for its literary implications, but because he regards it as conveying an actual truth about the nature of the world: that is to say, he is a "realist" not only in a literary sense, but in a philosophical one. Both Abrams and Prickett, followed by Hilary Fraser (15), assume that Keble's poetic theory was influenced by Coleridge, but this is to ignore the extent to which Keble deliberately sets himself against the subjectivizing tendency of Coleridgean poetics. As Prickett himself implicitly recognizes, the whole thrust of Keble's poetics is against regarding poetry as the product merely of the poet's individual mind. ${ }^{8}$

The realist philosophical position evident in Keble's poetics reflects the influence of a British philosophical tradition which has been virtually ignored by modern literary critics (though currently the subject of a revival of interest amongst philosophers), the (so-called) "Common Sense School," of which Thomas Reid and his pupil Dugald Stewart are the best known representatives. The "Common Sense" philosophers argued against the skepticism of David Hume by appealing to fundamental, rationally unanalyzable intuitions (called by them "common sense") which, amongst other things, grounded our belief in God and in an external world. ${ }^{9}$

One important aspect of their position was the analogy they claimed between perception and language. Reid and his followers developed Berkeley's claim that the process of perceiving an external world was in important respects like the process of interpreting a language: in both cases, there is no natural relationship of resemblance between the material impression on our senses and what we end up understanding by it. The acoustic vibrations which constitute the material existence of a word are not in any way "like" the concept it evokes in our minds, and in the same way for Reid and other "Common Sense" philosophers our physical sensations bear no kind of "resemblance" to the world of our perceptions (a claim which they regarded as having been conclusively established by Hume's demonstration that it was impossible to justify our natural belief in an external world by a process of rational deduction from our sensations) (Reid 127-30). In the view of Reid and his followers, the world was filled with divinely instituted signs which, by a providential dispensation, our minds were enabled intuitively to decipher: all knowledge became for them a form of revelation (134). 
The affinity of this realist philosophical account of perception to the traditional Christian belief in typology was clear to late eighteenth- and early nineteenth-century theologians (cf. Magee 138), and can be seen to underlie Keble's assimilation of Wordsworthian poetics to the Tractarian religious outlook. If all perception is interpretation of a divine language, then, conversely, the metaphorical language of the Bible can be regarded as a mode of perception, possessing a reality, which is equal to any evidence of the senses. In this view typology, or use of Biblical metaphor, is not merely a literary game, but a vital reality inherent in our perceptions of the world, and the poetic language of a Wordsworth shares in this divinely guaranteed reality insofar as it is related to Biblical typology. From this brief outline of Keble's realist position, it will be apparent that it is utterly antithetical to Coleridgean poetics: for Keble to account for poetry in terms of the individual poet's psychology, as Coleridge does, would be to undermine both his theological and epistemological position.

For Keble, God guarantees the special reality of Biblical metaphors in a way which distinguishes them from the normal metaphors of human speech:

\begin{abstract}
The Author of Scripture is the Author of Nature. He made His creatures what they are, upholds them in their being, modifies it at His will, knows all their secret relations, associations, and properties. We know not how much there may be, far beyond mere metaphor and similitude, in His using the name of any one of His creatures, in a translated sense, to shadow out some thing invisible. But thus far we may seem to understand, that the object thus spoken of by Him is so far taken out of the number of ordinary figures of speech and resources of language, and partakes thenceforth of the nature of a Type ... Let an uninspired poet or theologian be never so ingenious in his comparisons between earthly things and heavenly, we cannot build any thing upon them; there is no particular certainty, much less any sacredness in them: but let the same words come out of the mouth of GOD, and we know that the resemblance was intended from the beginning and intended to be noticed and treasured up by us; it is therefore very nearly the case of a Type properly so called. (Keble 1839-43, 166-67)
\end{abstract}

Keble is concerned in this passage to establish the difference between the divine origin of "a Scriptural Type" and the human origin of a "mere illustration or analogy." What distinguishes the two for Keble is the very fact of the first having appeared in the inspired word of Scripture; this implies "that the event or observance itself to which we annex the figurative meaning was ordered ... from the beginning with reference to that meaning" (1839-43, 166-67). Keble's view here seems to invoke the doctrine of the literal inspiration of Scripture: God's dual role as Creator of the world and as divine Author of Scripture, means that Scriptural metaphors partake of the reality of the world itself, in a way that merely human metaphors can never do, so that the Type is, in an important sense, identical with Nature.

The crucial nature of the difference in epistemological status between Scriptural and nonscriptural "allusions to the works of nature" is apparent in the way Keble uses to illustrate this difference the key Type of Christian theology, Abraham's sacrifice of Isaac (1839-43, 166-67). If we knew of the sacrifice of Isaac only through the non-scriptural author Josephus, Keble argues, Christians might still have chosen to refer to the sacrifice of Isaac "by way of similitude and comparison" when discussing the Crucifixion, but it would not be possible to regard it as a Type. What underpins the typical status of the sacrifice of Isaac is the fact that it is recounted in Scripture, so that the comparison to the Crucifixion "must have been intended in the first sanctioning of the type, being the inevitable result, in all minds that fear GOD, and watch for the signs of His presence." For Keble, God himself has willed the 
comparison between the Crucifixion and the sacrifice of Isaac, in that the inclusion of the story of Abraham and Isaac within the inspired text has made it morally inevitable that a pious Christian will discover its resemblance to the Crucifixion. Keble suggests that the use in the inspired text of the Bible of metaphors taken from Nature has, in a similar way, made it morally inevitable that the pious Christian will discover religious significance in Nature, and that it is justifiable to claim that this religious significance is an objective feature of Nature itself, not merely a meaning attached to Nature by the individual consciousness.

As Keble points out, taken to its logical conclusion this typological outlook on the world implies that "the whole world of sense" potentially possesses spiritual meaning, since the natural Types of Scripture must inevitably become intimately associated with our experience of Nature as a whole, a process which is facilitated by the way in which in Scripture "so many of the chief visible objects are invested with spiritual meanings" (1839-43, 166-67). Religious belief for Keble offers the key to an entire renewal of our perceptions of very much the same kind as Coleridge in the Biographia Literaria attributes to the influence of Wordsworth's poetry. To put it in modern terms, religious perception of the world is for Keble an exercise in defamiliarization of a kind which I will be suggesting is also characteristic of the aesthetic of Yonge's novels.

My argument in this paper will be that Yonge's novels share Keble's brand of typological realism. I do not want to suggest, however, that this is an unproblematic heritage for Yonge as a novelist; indeed, I think that much of what makes Yonge a more interesting writer than Keble is her struggle with the implications of typological realism for the novelistic representation of experience. Famously, Yonge submitted her novels to Keble, her neighbor and a close personal friend, for correction (Battiscombe 72). Feminist critics have often interpreted this habit of Yonge's as a gesture of submission to male authority, but from the perspective I have been outlining it might be viewed as indicating some anxiety on Yonge's part about the double-bind inherent in the demands of typological realism in the novel.

Typological realism is more problematic for Yonge than it is for Keble because of the novel form's basic demand that the novelist create a fictional world, a requirement which threatens to disrupt that direct communication between the mind and God to which intuitionist and typological thinkers appealed. An article in the Monthly Packet, the educational magazine for young people which Yonge edited, suggests considerable ambivalence about the moral influence of the novel form. Even novels which are in themselves morally sound, the writer argues, can have a harmful effect on the minds of readers owing to the unreal nature of the worlds they create: novels play upon the feelings which excite us to action without actually providing any scope for that action, and in so doing they tend to weaken our capacity to form virtuous habits. The very unreality of novels enfeebles those divinely implanted intuitions which are our guide to action in the real world, and the only remedy for this, the writer suggests, is to be careful not to read too many novels (B.L.K. 472-73).

The danger of the novel form, then, is that it encourages an excessive subjectivity which tends to insulate the mind from its native intuitions of the divine reality outside itself. This negative characterization of the inherent tendencies of the novel form is reinforced by a further article published in the Monthly Packet a couple of years later, in which novelistic modes of characterization are held responsible for encouraging egotism. The problem with novels, the writer suggests, is that they tend to instill an excessively self-analytical and self-conscious attitude towards our own characters, by promoting a habit of mind in which our own actions are regarded as those of a character in a novel. This mindset is responsible for an isolation 
from those beneficial moral intuitions naturally prompted by the external world, and hence for "undisciplined passions," which God must "tame by chastening and trials" (Anon 517).

These articles indicate that Yonge must have regarded her commitment to typological realism, both as literary style and religious-philosophical position, as demanding a high degree of self-consciousness in her work as a novelist. As her comments on "sensation fiction" show, Yonge was aware that novelistic realism had a tendency to degenerate into naturalism and sensationalism (Yonge 1965, 192): from the point of view I have been suggesting Yonge and Keble shared, this is "unreal" because it implies it is possible to lead lives which have no dimension which transcends the material world. For this reason, Yonge's own novels, even where they incorporate incident which might find a place in a sensation novel, such as the conviction of an innocent youth for murder in The Trial, resolutely downplay such elements in favor of a concentration on "the trivial round, the common task" (Keble 1914, L. 53).

Yonge also seems to have been aware, however, of dangers posed by including typological elements in her fiction. In her novel The Pillars of the House, which belongs to a later phase of her career, one of the characters is counselled against looking out for "types" by a clergyman (Yonge 1901, 1: 171; ch. 10); it is no coincidence that this character, Geraldine, is consistently described as over-sensitive and imaginative to a degree that endangers her health. For Yonge, then, the kind of imaginative correspondences in which typology deals themselves have the potential to lock readers into a merely subjective (and therefore morally harmful) novelistic world if these correspondences are ones that are merely fabricated by the author's imagination.

Since both typology and realism, considered in isolation, pose the threat of a morally sapping subjectivity in the novel, the difficulty of the typological realism to which Yonge is committed is how to combine the two. For Yonge, realism must include a transcendent, or typological, dimension in order to avoid the kind of isolated self-consciousness which she sees "sensation fiction" as promoting, but conversely that typological dimension must be real, in the sense that it is recognized as transcending the consciousness of the author. Yonge's fictional style can be seen as an attempt to negotiate the fine line between the potential unreality of self-regarding religious rhetoric, on the one hand, and what she would have regarded as the equally "unreal" state of mind induced by the mere proliferation of novelistic incident, on the other. ${ }^{10}$

One of the most obviously typological moments in The Heir of Redclyffe is the episode where Guy, the hero of the novel, after having been falsely accused of gambling, strives to keep his hereditarily fierce temper and avoid challenging his accuser, his cousin Philip, to a duel:

The sun was setting opposite to him, in a flood of gold, - a ruddy ball, surrounded with its pomp of clouds, on the dazzling sweep of horizon. That sight recalled him not only to himself, but to his true and better self; the good angel so close to him for the twenty years of his life, had been driven aloof but for a moment, and now, either that, or a still higher and holier power, made the setting sun bring to his mind, almost to his ear, the words, -

Let not the sun go down upon your wrath,

Neither give place to the devil.

Guy had what some would call a vivid imagination, others a lively faith. He shuddered; then, his elbows on his knees, and his hands clasped over his brow, he sat, bending forward, with his eyes closed, wrought up in a fearful struggle; while it was to him as if he saw the hereditary demon of the Morvilles watching by his side, to take full possession of him as a rightful prey, unless the battle was 
fought and won before that red orb had passed out of sight. Yes, the besetting fiend of his family the spirit of defiance and resentment - that was driving him, even now, while realizing its presence, to disregard all thoughts save of the revenge for which he could barter everything - every hope once precious to him.

It was horror at such wickedness that first checked him, and brought him back to the combat. His was not a temper that was satisfied with half measures. He locked his hands more rigidly together, vowing to compel himself, ere he left the spot, to forgive his enemy - forgive him candidly - forgive him, so as never again to have to say, "I forgive him!" He did not try to think, for reflection only lashed his sense of the wrong: but, as if there was power in the words alone, he forced his lips to repeat, "Forgive us our trespasses, as we forgive them that trespass against us."

Coldly and hardly were they spoken at first; again he pronounced them, again, again, - each time the tone was softer, each time they came more from the heart. At last the remembrance of greater wrongs and worse revilings came upon him; his eyes filled with tears, the most subduing and healing of all thoughts - that of the great Example - became present to him; the foe was driven back. (Yonge 1997, 225-26; ch. 16).

Yonge's use of free indirect discourse in this passage allows her to blend psychological description of Guy's state of mind with Biblical allusion, in such a way that when Guy begins to think of "the great Example," Jesus, the reader can hardly fail to recognize that the entire scene Yonge has created is based on the Temptation in the Wilderness - Guy has rushed out into the moorland, is seated in a high place (like the "pinnacle of the temple" [Matthew 4.5]) and is resisting "the hereditary demon of his family" in the same way that Jesus overcame not only Satan, but the hereditary influence of Original Sin. Having established this parallel between Guy and Christ, Yonge is fairly discreet about employing it, but it is noticeable that Guy's awakening to a new religious life occurs at Christmas, which could be interpreted as a birth of the Christ child within the individual soul, and that his rehabilitation with the Edmonstones, from whom the accusation of gambling has alienated him, occurs at Easter, and so represents a kind of resurrection.

At one level, of course, Yonge's use of typology here could be seen as a development of the Romantic symbol. However, it is important to distinguish between Tractarian typology and some varieties of Romanticism: as Keble's discussion of typology makes clear, one of the essential characteristics of the Type is that it is authorized by the inspired language of Scripture itself. From the Tractarian point of view, this establishes the essential objectivity of typological language, freeing it from the imputation of fancifulness or morbidity.

Typology, then, is the opposite of the "pathetic fallacy" of which Ruskin accuses Coleridge and other writers (Ruskin 5: 201-20). Keble himself, in his Lectures on Poetry, plainly regards Wordsworth as an essentially typological writer, and the distinction between a kind of figurative language which projects the writer's feelings onto the external world in a Shelleyan manner, and a kind which respects the objectivity of the external world is central to later nineteenth-century discussions of Wordsworth.

Stopford Brooke, for example, in his 1874 book Theology in the English Poets, makes a distinction between the essential theological soundness of Wordsworth's poetry and the theological unsoundness of Coleridge on precisely these grounds (91-93). In Wordsworth's poetry, despite the deep feeling which animates it, the distinction between mind and the world outside it is preserved intact, and this allows for God's moral prompting through natural objects (an example of this in Yonge would be the way in which Guy's response to the beauty of the setting sun allows his "best self" or "a still higher and holier power" to bring 
the Biblical text to mind). By contrast, for Stopford Brooke, Coleridge's poetry is essentially morbid because it blurs the distinction between mind and world in a manner which prevents this kind of divine influence from reaching the mind: if the mind is projected onto the external world in what Ruskin calls the "pathetic fallacy," then the natural world cannot exercise any moral influence, being ignored in favor of the mind's own projections, and for Brooke this is the explanation both for Coleridge's moral weakness and for his unsound religious opinions. Yonge seems to making a very similar point in a later discussion of Byron between Guy and Philip (Yonge 1997, 400; ch. 30).

The requirements of Tractarian typology, then, constrain Yonge to negotiate a stylistic tightrope in the passage we have just been examining. Although Yonge uses typology to make Guy's moral struggle present to her readers, she must be careful not to allow this psychological dimension to obliterate the external landscape which Guy occupies. This is why, for example, she is very careful to state that it is not the setting sun itself which brings the Biblical text to Guy's mind, but his "best self" or "a still higher and holier power" acting by means of the sun. This is an important distinction, because if the sun and the Biblical text were allowed to become symbolically fused, the distinction between mind and world would be lost, and the passage would be encouraging a kind of projective religious emotionalism which Yonge elsewhere warns against (Yonge 1976, 269-70; ch. 18, 326; ch. 21).

Although Yonge is careful to guard against a Romantic symbolic fusion in this particular passage, from a Tractarian perspective it might be questioned whether the novel as a whole really succeeds in preserving the distinction between religious significance and its sensory embodiment on which the validity and orthodoxy of typology depend. Guy is perhaps too obviously the embodiment of Christlikeness, and Yonge may have come to feel that the overall effect of The Heir of Redclyffe was to encourage that projection of religious emotion onto the external world which we have seen her careful to guard against on a local level.

Certainly in her following novel The Castle Builders, which uses a very similar set of plot-elements, the consumptive young clergyman whose nobility of character corresponds to Guy is kept offstage throughout the entire narrative, and the chief representative of true religious values who, in a scene which parallels the shipwreck in The Heir of Redclyffe, comes to the rescue of the silly heroines when they are cut off by the sea, is the "dry" and repelling clergyman Mr Brent (189). And in the later novel The Pillars of the House, the kind of explicit typological writing we have seen in The Heir of Redclyffe is entirely absent: the only allusion to typology is in connection with the artistic and overly excitable invalid, Geraldine (Yonge 1901, 1: 171; ch. 10). This may indicate that Yonge came to regard explicitly typological modes of writing as being in conflict with her novels' focus on the nature of religious evidence, a conflict already evident in readers' reactions to the character of Philip in The Heir of Redclyffe.

So far, then, I have been attempting to distinguish between the Tractarian account of typology and Romantic theories of the symbol, which may superficially appear similar. It would probably not be going too far to say that the whole point of the Type for the Tractarians is that it is not the Symbol, in that it preserves a separation between the objects of the material world and the significance which the mind finds in those objects. For the Tractarians, even Nature is not meaningful in itself, but only insofar as a higher power has attached meanings to natural objects, a point which we have found both in Yonge's description of Guy's resistance to temptation and in Keble's Tract 89. 
Yonge's attempt to resist the dangers of subjectivity can be seen in her methods of characterization and her treatment of the narratorial voice. As Sandbach-Dahlström has noted, psychological complexity in Yonge's characterization is always associated with moral failure: good characters in Yonge have no "psychology" (Sandbach-Dahlström, 42). This does not necessarily mean that Yonge's characterization is always static, but that the narrative focus of her novels tends to shift away from those characters who have successfully come through their moral struggles. This is true, for example of the character of Felix in The Pillars of the House, Kate after her spiritual awakening in The Castle Builders and Guy in The Heir of Redclyffe.

In view of the anxieties about the moral nature of subjectivity we have seen expressed in the Monthly Packet, Yonge's assumption that psychological complexity is morally pernicious becomes explicable. For Yonge, the psychologically complex character is in a state of mind which is cut off from the common, fundamental intuitions of divine reality on which moral health depends; that is to say, they are in a condition which exactly resembles that of the reader of too many novels. The implicit equation in Yonge's work between the morally suspect status of the novel reader and the morbidly self-regarding psychology which makes for an "interesting" novelistic character is suggested by the echo of the title of her novel The Castle Builders in the Monthly Packet writer's comment that the "loss of energy in the character" occasioned by excessive novel-reading is only outdone by "the still more enervating habit of 'building castles in the air"'(B.L.K 473): Yonge's characters in that novel drift desultorily from one project to another in a search for "excitement" (cf. Yonge 1976, 326; ch. 21) which parallels other contemporaries' descriptions of the quest of the reader of "sensation fiction" for ever more striking novelistic incident (Mansel 485-87).

As a novel-writer, Yonge is in the business of producing what Stanley Fish calls "selfconsuming artifacts," novels which draw attention to the fictional status of their own discourse, with all the moral limitations which for Yonge that fictional status implies. Novelistic realism can only depict the morally failing character, because the unreality of novelistic discourse stands in an analogical relationship to the "unreality" (or alienation from God-given moral intuitions) of such characters' state of mind: like the novelist, these characters construct for themselves a world which is independent of God. As Sandbach-Dahlström notes, the primary moral fault displayed by characters in Yonge's novels is a condition of "self-sufficiency," the same independence from the externality of the real which the world of a novel potentially possesses (150).

Yonge's suspicion of the moral effects of the novel form means that her aim as a novelist is to shock her readers out of an uncritical absorption in her own novelistic discourse, and it is here that the typological element in her narratives becomes important. Because for Yonge this typological symbolism should serve as a means by which her readers are enabled to transcend the purely "sensational" dimension of novelistic discourse (just as her characters are shown as transcending through intuition the material dimensions of their lives), it is vital that it is never integrated into novelistic discourse by being explicitly commented on. Typology, as an irruption of divine reality into the self-enclosed discourse of the novel, is made in the reader's experience to stand in for the unrepresentable intuitions whereby Yonge's characters transcend the material world.

The Tractarian "reserve" with which Yonge presents typological elements is responsible for that demotion of the authority of the narratorial voice on which critics of her novels have commented. The narrator of a Charlotte Yonge novel, although not explicitly characterized, 
is nevertheless not "omniscient" (Sandbach-Dahlström 12), with the result that characters in the novel, the figure of the author and Yonge's reader are placed on a level in regard to interpretation of events. Yonge's novels thus come to exhibit a curious kind of self-reflexivity in which questions about interpretation debated by characters in the novel are also ones which readers themselves must address, and to which the narratorial voice can offer no answers.

\section{Typological Significance in The Heir of Redclyffe: The Relation between Faith and Reason}

THE HEIR OF REDCLYFFE provides a privileged site in which to explore the relationship between typology and realism in Yonge's novels generally, because the potential conflict between these modes of apprehending the world is thematized at an explicit level by the plot and reflected in different styles of writing. It has been generally recognized by critics that Yonge's portrayal of the character of Guy, last scion of the accursed ancient family of the Morvilles, is influenced by Romance writing (Yonge 1997, xi-xviii; Sandbach-Dahlström 28-37). Philip, Guy's poor cousin, on the other hand, is presented in a much more novelistic and psychologized fashion, as acting under the influence of jealous feelings of which he is himself unaware (Yonge 1997, 267; ch. 19, 469; ch. 36).

It has also been recognized by critics that Yonge's portrayal of Philip and his inadvertently corrupting influence on his cousin Laura, one of the daughters of the Edmonstone family which provides a substitute home for both him and Guy, is intended as a critique of Utilitarianism (xviii). One signal of Philip's identification with Utilitarian rationalism is the way he encourages Laura in mathematical studies in order to "strengthen her mind" so that she will better be able to exercise the self-command necessary to keep their clandestine engagement a secret (153; ch. 10). Philip is also consistently portrayed as engaging in consequentialist moral reasoning (cf. 111; ch. 7), to such an extent that he is liable to attribute quite unrealistic "ultra-prudential" motives to other characters (259; ch. 19); "prudence" is a quality repeatedly ascribed to him by other characters and by the narratorial voice.

What has not been noticed by critics, however, is the extent to which the implicit identification of Philip with Utilitarianism informs the entirety of The Heir of Redclyffe, down to small details of plot and characterization, with the result that the entire novel can be read in typological terms, as a kind of allegory of the doubting nineteenth-century soul's path to faith. The modernity of Philip's novelistic characterization is thus intended to function for readers as a sign of his status as a nineteenth-century Everyman, whilst the Romance elements associated with Guy's characterization are supposed to indicate his moral transcendence of the material world. Late in the book, for example, a painter sees in Guy's expression, as he gazes up at some stained windows, the model he needs for his picture of Sir Galahad (403; ch. 30), a fairly obvious hint on Yonge's part.

As Sandbach-Dahlström notes, Guy is a Christ figure, a typological correspondence which is established at a fairly early point in the plot. It may fairly be questioned, however, whether Yonge in this particular novel is altogether successful in coordinating the realist elements of the plot with the demands of these typological significances. Yonge's first readers jibbed at the extent to which she seems to expect us to sympathize with Philip after the moral breakdown of his repentance, with even her brother declaring that he felt Philip deserved a good kicking (Wolff 134-35). Philip's representative status of course requires this sympathy, but he has been portrayed so consistently by Yonge as a self-absorbed and domineering prig 
(cf. Yonge 1997, 240; ch. 17) - in a way which, as we shall see, is also required by the novel's typological structure - that sympathy is difficult to grant (though the difficulties the Edmonstone family find in forgiving Philip, despite the pleading for him by Guy and his wife Amy, parallel readers' difficulties in this respect [cf. 537: ch. 40]).

Another tension in the book for which typological elements are responsible is represented by Yonge's portrayal of the consequences of Laura's secret engagement. As Laura comments towards the end of the book, as a result even Philip "cannot have that honouring, trusting, confiding love that ... he would have had if I had cared first for what became me" (Yonge 1997, 583; ch. 43) a judgement in which Philip himself seems to concur even when he is blaming himself for this state of affairs, saying "I taught you to take my dictum for law, and abused your trust, and perverted all the best and most precious qualities" ( 584 ; ch. 43). Yonge makes clear that this condition is permanent when she comments on the final page that despite their outward prosperity, Philip and Laura led "a harassed, anxious life with little of repose or relief" (594; ch. 44).

Typologically, this final "harassed" state is required by the moral "fall" Laura has undergone through taking Philip's word as law rather than trusting to her own God-given moral intuitions (even before discovery of the engagement, Laura is described as "harassed" and out of sorts [Yonge 1997, 172; ch. 12]). Laura, like Eve, has committed the original sin of aspiring to the judgment of good and evil for herself. Yonge seems to intend us to contrast Laura's mistaken reliance on Philip's rationalizing with her sister Amy's unquestioning dependence on intuition. In a rather melodramatic incident when Guy and Amy are on their honeymoon in the Alps, Amy slips and finds herself hanging onto some brushwood just above a precipice, and when Guy comes to her rescue he demands that she raise one hand so that he can pull her up: although Amy feels "as if relinquishing her grasp of the tree was certain destruction," her "habit of implicit confidence and obedience" leads her to comply, and Guy pulls her up "even while the bush to which she had trusted was detaching itself, almost uprooted by her weight!" (392; ch. 30). As Yonge comments, "If she had waited a second she would have been lost, but her confidence had been her safety" - an implicit contrast to the lack of confidence Laura has shown in her family's reactions to her relationship with Philip.

It is noticeable that Yonge treats Laura's lapse into Utilitarian moral calculation much more harshly than she does Philip's, and this might be seen as her version of the Victorian sexual double standard: Laura's rationalism makes her into Philip's "slave and automaton," as her brother Charles describes it (Yonge 1997, 447; ch. 34), because she is not exposed to the wider experience which would eventually excite the moral intutions to make her feel her error. Even Victorian readers, however, felt that the blighted life Yonge suggests Laura is doomed to lead was a punishment out of all proportion to her actual offence, regarded at the literal level of plot. R. H. Hutton, for example, commented that Yonge's view of Laura's transgression was "extravagant beyond measure ... entirely the old feudal notion, that in the father resided the right to give or withhold the daughter's hand, and that in giving it herself she committed an act of petty treason," and finds the author guilty of "that morbid introspectiveness which is the worst form of ethical speculation" (215-16). Hutton's use of the word "morbid" points to the danger of subjectivity, which I have already suggested Yonge recognized in her use of typological correspondences. The very obviousness of some of the typology in The Heir of Redclyffe lays it open to this kind of criticism, the justness of which Yonge herself seems to have recognized. 
Yonge does, however, manage very successfully to infuse one of the major plot elements in The Heir of Redclyffe with typological significance - so successfully, in fact, that this typological aspect does not appear to have registered in previous commentary on the book. Philip's married sister (another female figure whose rationalism Yonge appears to treat as more morally culpable than Philip's), sends word in a letter that she has seen a $£ 30$ check of Guy's being paid to a notorious member of the gambling fraternity, which she takes as evidence that Guy has succumbed to this hereditary vice of the Morvilles (201-02; ch. 14). Guy has in fact written this check for his weak-minded and impoverished musician uncle, to get him out of a scrape (213-20; ch. 15). Guy in the meantime has requested $£ 1000$ from his guardian, Mr. Edmondstone, which he intends as a donation to an Anglican sisterhood which is being founded (221; ch. 15). Philip brings his sister's letter to Mr. Edmonstone's attention, and, taken in conjunction with the request for $£ 1000$, this suggests that Guy has become habitually addicted to gambling. Guy cannot explain either the check (because this would expose his uncle) nor his request for the $£ 1000$, because Philip's sister is at the head of a party against Miss Wellwood, the would-be founder of the sisterhood, and would use this against her if she heard of it $(229$; ch. 17).

This misunderstanding dominates the rest of the novel's plot, largely because of what is shown to be Philip's all too consistent rationality. Philip spurs his rather woolly-minded uncle on to enquire into the matter, dictating the letter himself, and when Guy writes in answer that he denies on his honor that he has been involved in gambling, although he cannot explain the circumstances on which the suspicion is grounded, it is Philip who will not let his uncle be satisfied with Guy's word. Philip takes it upon himself to go to Oxford to enquire about Guy's behavior at university, and when he finds no evidence of dissipation on Guy's part will not admit that this strengthens Guy's cause, though Yonge comments that he feels "like a lawyer whose case is breaking down" (257; ch. 19).

During Philip's absence abroad, Guy is rehabilitated with the Edmonstones owing to his heroic involvement in a rescue from a shipwreck: although as Charles points out (322; ch. 24), this does not amount to a logical proof of his innocence, it does encourage Mr. Edmonstone to meet Guy in London personally, where by a minor coincidence the matter of the check is cleared up. Philip, however, will not accept that this clears Guy for the imputation of gambling (360-61; ch. 28) - after all, there is still the request for $£ 1000$ to be accounted for and refuses to attend Guy's subsequent marriage to his cousin Amy, Laura's sister (365; ch. 28). Even after Guy has devotedly nursed him back to health, after the fever to which he has succumbed on his travels in Italy, Philip still harbors a doubt of Guy's innocence, though Yonge comments that he "had rather believe Guy blameless" (438; ch. 33), and he is only finally convinced when Guy, having caught the fever himself, is going through on his deathbed the provisions of his will, which include a bequest to the Anglican sisterhood for which he had requested the $£ 1000$.

Philip goes on demanding proof of Guy's innocence long after the other characters have been convinced of the purity of his character, and is consistently associated (along with Laura, who is under his influence) with the language of moral reasoning and calculation. One of the key moments in the characterization of Philip as an exemplar of strong-minded rationality comes when he confronts Guy in his rooms at Oxford:

Philip had been used to feel men's wills and characters bend and give way beneath his superior force of mind. They might, like Charles, chafe and rage, but his calmness always gave him the ascendant almost 
without exertion, and few people had ever come into contact with him without a certain submission of will or opinion. With Guy alone it was not so; he had been sensible of it once or twice before; he had no mastery and could no more bend that spirit than a bar of steel. This he could not bear, for it obliged him to be continually making efforts to preserve his own sense of superiority. (255; ch. 19)

Philip's consistent and unwavering rationality gives him no advantage over Guy, whose strength springs from the sensitivity with which he responds to his moral intuitions rather than from any brilliance of intellect. At several significant points in the book, Philip's own over-confidence in his intellectual power leads him to overstep the mark where Guy is concerned, and so to forfeit the authority which his mental superiority had gained him. He responds, for instance, to the news of Amy's engagement to Guy (after the circumstances surrounding his check to the gambler have come out), with a letter expressing his "surprise" that Mr. Edmonstone has been satisfied with "so incomplete an explanation of circumstances" and suggesting that Guy be put on a period of probation before he is allowed to marry Amy. Mr. Edmonstone finds this a piece of impertinence, and although Guy self-denyingly tries to defend Philip by arguing that there is "justice and reason" in Philip's letter, the only person who does not find Philip's behavior inappropriate is Laura - a mark of how much she is under his influence (346-51; ch. 27). At a later point in the book, too, when after her marriage Philip condescendingly tries to give Amy advice on how to handle a man of the character he takes Guy to be, she replies "I think you forget to whom you are speaking," leaving him "as much taken by surprise as if a dove had flown in his face," Philip's gaffe is that, in presuming on his intellectual superiority, he has "forgotten that she was Lady Morville, not the cousin Amy with whom Guy's character might be freely discussed" (407-08; ch. 30).

Philip's rationalistic approach to life is thus linked by Yonge with his inability to perceive the true nature of Guy's character and with his tendency to usurp the authority which properly belongs to others (notably Mr. Edmonstone). It is possible to read typologically these aspects of what is a very convincingly realist plot, as corresponding to what Yonge would have perceived as an excessive domination of Utilitarian reason in nineteenth-century Britain generally. Given the typological equation between Guy and Christ, Philip's insistence on logical proofs of Guy's character, and his inability to respond to the intuitive trust which Guy awakens in those who come in contact with him, make him a "type" of the tendency of misplaced rationalism to weaken the mind's intuitive awareness of the source of religious belief in a personal response to God by demanding inappropriate kinds of evidence for religious belief. Believing in Christ, Yonge seems to be suggesting in The Heir of Redclyffe, is like believing in a person: the demand for logical evidence by its very nature must obstruct such a belief, whose essence is trust.

This typological reading of The Heir of Redclyffe is made more plausible by the similarity of the relationship in the novel between Faith, in the person of Guy, and Reason, in the person of Philip, to Newman's account of the nature of religious belief in his 1843 Sermons Preached Before the University of Oxford, a book which Yonge would certainly have known. Newman was influenced by the same British intuitionist tradition of philosophical realism to which I have suggested Keble's and Yonge's typological poetics was indebted, so Yonge's apparent adoption of the terms of his argument is not surprising. ${ }^{11}$

Newman argues in his sermon "The Usurpations of Reason" that "there is no necessary connexion between the intellectual and moral principles of our nature" (55), claiming, in a phrase which might stand as a summary of the relationship between Guy and Philip, that "the 
history of Revelation... [is] the triumph of the moral powers of man over the intellectual, of holiness over ability, far more than of mind over brute force" (57). One of Newman's principal targets in the sermon is the rationalistic tradition of theology associated with William Paley. Since for Newman reason by its very nature is incapable of making us morally better or more religious, the rationalistic seeking of "evidences" for Christianity cannot in fact benefit true religion, but can only represent an essentially self-seeking aggrandizement of the authority of Reason itself through an extension of rational modes of enquiry beyond their proper province (69).

In a gesture, which is reminiscent of Reid's and Stewart's philosophical intuitionism, Newman appeals to essentially non-rational intuitions as the true source of religious belief:

\begin{abstract}
In matter of fact, how many men do we suppose, in a century, out of the whole body of Christians, have been primarily brought to belief, or retained in it, by an intimate and lively perception of the force of what are technically called the Evidences? And why are there so few? Because to the mind already familiar with the truths of Natural Religion, enough of evidence is at once afforded by the mere fact of the present existence of Christianity; which, viewed in its connexion with its principles and upholders and effects, bears on the face of it the signs of a divine ordinance in the very same way in which the visible world attests to its own divine origin; - a more accurate investigation, in which superior talents are brought into play, merely bringing to light an innumerable alternation of arguments, for and against it, which forms indeed an ever-increasing series in its behalf, but still does not get beyond the first suggestion of plain sense and religiously-trained reason; and in fact, perhaps, never comes to a determination. Nay, so alert is the instinctive power of an educated conscience, that by some secret faculty, and without any intelligible reasoning process, it seems to detect moral truth wherever it lies hid, and feels a conviction of its own accuracy which bystanders cannot account for. (66)
\end{abstract}

For Newman, the true sources of religious evidence are "the signs of a divine ordinance" which are intuitively apparent to everyone who is in a morally right frame of mind; intellectual ability can never go a step beyond this source of evidence; all it can do is multiply arguments which are in themselves inconclusive. Newman argues in a later sermon, using Christ's ministry to the apostles as an example, that because of the essentially moral nature of religious truth, the medium by which it is spread is not that of rational argument but of personal influence. Newman goes so far as to suggest, in a way which is very relevant to our previous discussion of the "reserve" and lack of explicit comment which is characteristic of Yonge's use of typology, that it may not be possible really to convey religious truth in language at all:

Moral truth will be least skilfully defended by those, as such, who are the genuine depositories of it ... it cannot be adequately explained and defended in words at all ... Its views and human language are incommensurable. For, after all, what is language but an artificial system adapted for particular purposes, which have been determined by our wants? And here, even at first sight, can we imagine that it has been framed with a view to ideas so refined, so foreign to the whole course of the world, as those which (as Scripture expresses it) "no man can learn," but the select remnant who are "redeemed from the earth," and in whose mouth "is found no guile"? Nor is it this heavenly language alone which is without its intellectual counterpart. Moral character in itself, whether good or bad, as exhibited in thought and conduct, surely cannot be duly represented in words. We may, indeed, by an effort, reduce it in a certain degree to this arbitrary medium; but in its combined dimensions it is as impossible to write and read a man (so to express it), as to give literal depth to a painted tablet. (84-85) 
Newman's argument suggests that the failure of the rationalizing Philip to grasp the nature of Guy's character is essentially the same as the failure of novelistic discourse to convey moral goodness. Goodness cannot be analyzed in words, it can only be experienced, so that the reader of The Heir of Redclyffe could be regarded as in very much the same position as Philip himself, in being excluded from the perception of Guy's true character by the very necessity of articulating that perception in language. That Yonge agrees with Newman about the personal nature of moral truth is suggested in The Heir of Redclyffe by Charles's trust that if Mr. Edmonstone can once be brought to meet Guy, Guy's "personal influence" will convince him of the true nature of his character (Yonge 1997, 323-24; ch. 24).

Newman's claim that the true grounds of faith are intuitions that simply cannot be articulated in rational argument is reflected in the inconclusive nature of the only proofs Philip can find of Guy's moral character. The question about Guy's character can stand in a typological relationship to the question of religious faith in Yonge's novel, because, as Newman points out, both stand in a similarly incommensurable relationship to the intellectual standards to which rational argument appeals. Philip's tendency to overstep proper bounds of behaviour and lay down the law to other people can also be understood to correspond typologically to the tendency of Reason in the modern age, as Newman sees it, to attempt to aggrandize itself in areas where it is, strictly speaking, incompetent. It is significant that Yonge stresses throughout Guy's comparative lack of intellectual acuteness: unlike Philip, he is no great scholar, and has to struggle to gain admission to Oxford. Guy's inability to defend himself against Philip's accusations reflects Newman's argument in his sermon "Personal Influence, the Means of Propagating the Truth" that "the minute intellect of inferior men has its moment of triumph" even over "some of the most deeply-exercised and variously gifted Christians" (Newman 84).

\section{Utilitarian Reason and the Theory of Fiction in The Heir of Redclyffe}

SO FAR WE HAVE SEEN how Yonge integrates a typological dimension into the realist narrative of The Heir of Redclyffe. I would now like briefly to explore some of the wider implications of the critique of Utilitarian reason which informs Yonge's plot, by suggesting that typology in The Heir of Redclyffe is not just a form of reading that can be applied to narrative events, but a view of the world whose tenability is questioned by characters in the novel. Yonge's novel self-consciously interrogates its own typological mode of realism in a way that develops, on a fairly explicit thematic level, an account of the purpose of fiction itself.

We can legitimately oppose the theory of realism which is implicitly developed in The Heir of Redclyffe to Levine's The Realistic Imagination, because they arguably share a common reference point in the philosophy of J. S. Mill. Levine, as I suggested earlier, describes the "empiricism" he finds characteristic of the realist novel in terms derived from Mill, as essentially a process of induction from particulars. Philip's insistence, in The Heir of Redclyffe, on the need to find empirically verifiable evidence, rather than relying on intuition to justify Guy's character, can be seen as a dramatization of the process of induction described by Mill, and its ultimate insufficiency. The novel's 1853 publication date makes this identification of Philip's remorseless "logic" with Mill's philosophical position historically plausible - Mill's A System of Logic had already passed through several editions, and had been attacked at length in the Tractarian affiliated journal The British Critic (Packe 272). 
Yonge expects her readers to interrogate critically the typological element in her fiction, as her characters also do, and although this feature of her writing is relatively undeveloped in The Heir of Redclyffe (an early novel in her oeuvre), it becomes more important in later writing. For example, Yonge's presentation of the way in which Guy comes to be suspected of gambling, through letters from Philip's sister which are then followed by Philip's interview with Mr. Edmonstone and their surprise at Guy's application for $£ 1000$, leaves open the possibility that Guy may in fact have gambled - though this is then foreclosed in the subsequent chapter (Yonge 1997, 199-209; ch. 14). In her 1864 novel The Trial, however, the possibility that one of the central characters may in fact be guilty of murder is not definitively dispelled until a very late stage of the plot (Yonge, 1891, 290-93; ch. 25). Yonge challenges her readers to endorse the intuitive responses of her good characters, and thus subscribe to the typologically inflected philosophical intuitionism which constitutes the worldview of her novels, but she does require that this choice between rationalist and intuitionist worldviews be a conscious decision on the part of her readers, as it is on the part of the characters.

It is in the provoking of this kind of self-conscious response on the part of the reader, rather than in any overtly didactic message, that I would suggest Yonge sees the purpose of her novels to lie. This does not, however, make Yonge into some kind of religious liberal; indeed, as Hutton complains, she regards her own Tractarian position as the only one that is intellectually justified. ${ }^{12}$ The kind of interpretative openness that is built into her fictional style can co-exist in Yonge's work with a very firm set of doctrinal underpinnings because she regards realist fictional form as having an intrinsic tendency to steer the reader in the direction of Tractarian doctrinal correctness. Yonge does not feel the need to be a didactic novelist, I would argue, because in her view the very process whereby a novelist represents human experience linguistically is a guarantee of the religious truth of her works, provided only that the representation has at least some element of authenticity.

In The Heir of Redclyffe, this view of the potential moral and religious value of realist novel-form is apparent in the reactions of characters to the news of Philip and Laura's clandestine engagement. Amy, for example, comments that Laura's concealment of Philip's attachment to her can be put down to the fact that Philip discouraged her from reading novels and so she was unaware of the full implications of what she was doing (Yonge 1997, 426; ch. 32). Charles also comments on the strange "incompatibility of so novelish and imprudent a proceeding with the cautious, thoughtful character of both parties" (449; ch. 34), and Philip and Laura's marriage is repeatedly associated with the dénouement of a novel. The implication is that those who do not read novels are destined to live them out $(533 ; \mathrm{ch} .40$, 545; ch. 41, 579; ch. 43).

This ironic association of Philip and Laura with the kind of impulsive behavior found in novels forms part of an aspect of Yonge's critique of Utilitarian rationalism which we have not so far examined. Yonge portrays Philip's excessively logical way of thinking as leading him into morally questionable behavior, and eventually into downright foolishness. In the matter of his clandestine engagement with Laura, Yonge makes clear that Philip reasons himself into believing that they are "doing nothing in an underhand way" (Yonge 1997, 271; ch. 20), and this is also true of his behavior towards Guy, where his unconscious jealousy and "malignity" are apparent to other characters (265; ch. 20), but concealed from Philip himself by his ability to rationalize his own motives. Philip's excessively rationalizing approach to life eventually betrays him into catching the fever, because his quickness in finding ulterior motives for other characters' actions leads him to disregard Amy and Guy's attempts to 
dissuade him from continuing with his travel plans, on the grounds that "the whole objection was caused by Guy's dislike to submit to him, and a fit of impatience of which Amy was the victim," an impression which is based on a suspicion "that his cousin wanted to escape from his surveillance and follow the bent of his inclinations" towards gambling (406-07; ch. 30).

Philip's very rationality, then, leads him into making a notably irrational decision. Yonge emphasizes the way in which Philip's logic is to be the downfall of himself and Laura at an early point in the novel when describing Philip's advice to Laura to "strengthen her mind" by studying algebra:

Philip, with all his sense, was mystifying himself, because he was departing from right, the only true "good sense". His right judgement in all things was becoming obscured, so he talked metaphysical jargon instead of plain practical truth, and thought he was teaching Laura to strengthen her powers of mind, instead of giving way to dreams, when he was only leading her to stifle meditation, and thus securing her complete submission to himself. (153-54; ch. 10)

Unbeknownst to himself, Philip's logic is really only a way of asserting his male power over Laura. This point is reiterated towards the end of the novel, where a repentant Philip criticizes Laura for "idolizing" him in a manner which is unhealthy for them both, and their relationship is contrasted with that between Guy and Amy. Amy recalls that "dear Guy ... kept it always before my eyes from the very first that we were to look to something else besides each other" and comments to Laura that "if that other is first, it would make you have some other standard of right besides himself; then you would be a stay and help to him" (553; ch. 42).

Yonge shows that the entirely this-worldly dimension of Philip's logic has made his relationship with Laura morbid and unhealthy, preventing it from being a relationship between equals. Laura can only submit her mind entirely to Philip, because his logic has excluded any standard beyond her worldly experience by which to judge him - and worldly experience is something in which, as a man, he is always going to be her superior. Yonge here seems to be making a case for an intuitionist philosophical position as the only one which can guarantee female independence: if Laura had referred herself to "that other" (i.e., her moral intuitions of God) she would have been able to judge Philip in a way that would ultimately have been helpful to him.

We can extend Yonge's characterization of the relationship between Philip and Laura into an account of the function of novelistic realism which is radically opposed to Levine's equation of realism with induction, particularly if we remember that Yonge described the relationship between Lewes and George Eliot, and its influence on the writing of Middlemarch, in very similar terms. Yonge, it will be recalled, found Eliot's "imagination tarnished" by the "blighting and poisoning" influence of Lewes (qtd. in Tillotson 69). Taking a hint from Edwin Eigner's comment that characters in the "metaphysical novel" often embody particular faculties of the mind, we could plausibly regard Philip as standing for the faculty of Reason and Laura for the faculty of Imagination. But we must not think, however, that Yonge's description of Laura's moral corruption through her submission to Philip's intellect implies a wholesale rejection of realism in favor of a "romance" which has cast off all responsibility to the world of experience, as Levine's oversimplified opposition between the two would indicate. To assert the legitimate authority of the imagination in the world of fiction, in the way which Yonge's description of the relationship between Laura and Philip 
implies, was not to reject all reference to the particularity of lived experience, since it was a commonplace of the kind of conservative feminist tradition of writing about women to which The Heir of Redclyffe belongs to regard them as endowed with that kind of Wordsworthian imaginative responsiveness to the particular and the detailed which also formed the basis of Ruskin's account of painting (cf. Ellis 28-32). Yonge is therefore not rejecting realism, but rejecting what a slightly later generation of novelists would call "naturalism," that is to say a kind of realism which is devoid of any intuition of a transcendent dimension of experience.

From this viewpoint, which reflects Common Sense philosophy's licensing of "natural typology," particularity and moral significance are not mutually contradictory in the way Levine assumes they must be in all realist writing. Levine's argument that the particularity of realist writing is inherently in conflict with any collective standard of morality such as religion reflects Mill's assertion that all rationality is based on "particular facts . . . collected by induction" (Mill 193). Mill's insistence on the particular as the foundation of all true logic implies, of course, that the judgment of the individual constitutes the final authority. Yonge's depiction of Philip and Laura's downfall through logic, I would argue, implies that this kind of Utilitarian logic is a recipe for moral anarchy, rather than moral freedom: Philip and Laura respect only their particular circumstances in making the decision to conceal the engagement, and Yonge shows this not only to be selfish but, ultimately, self-defeating, in that it perverts the relationship which they are attempting to protect.

The linkage Yonge creates between Philip and Laura's engagement and the kind of behavior to be found in novels suggests the close connection between the critique of Utilitarianism presented in The Heir of Redclyffe and Yonge's own theory of fiction. Soon after Philip's secret avowal of his attachment, Laura is "made very uncomfortable" by a cousin's declaration "that it was positively impossible and unnatural that the good heroine of some novel should have concealed her engagement from her parents" and feels she has to find "many excuses" (Yonge 1997, 174; ch. 12). For Yonge, it is obvious that the novel (even, as in this case, a bad novel) can excite moral intuitions whose truth can transcend particular circumstances - the irony in this passage is that the cousin towards the end of the book is encouraged by the example of Laura's secret engagement into an elopement.

Mill's utilitarian logic implicitly denies that a work of fiction can possess any kind of authority at all (since fiction by definition does not correspond to the "particular facts" from which all induction must proceed). Yonge's vindication in The Heir of Redclyffe of a typological intuitionism can thus be seen as a defense both of her position as a novelist and of her position as a woman writer. Whereas Mill's utilitarianism makes "general experience" the criterion of authority (the kind of experience in which a nineteenth-century woman could never have hoped to be the equal of a man), the philosophical intuitionism to which Yonge appeals makes language itself, as the intuition of a divine reality, into a source of authority (Magee 139-40; Whately 1878, 156-58; Reid 229). The linguistic nature of novels can thus become an argument for their authority, irrespective of the "experience" to which their authors can lay claim. Fiction's very generality, its lack of correspondence to the particular, can be productive of authority, because it involves a use of language which is in itself a source of evidence of the validity of the claims the novelist is making about the world. This is a position that must have had great appeal for Yonge, as a woman novelist.

Hutton, in the review of Yonge to which I have already referred, complains about the doctrinal basis of Yonge's fiction. Contrasting the modern "speculative age" with the 
"medieval Catholic ages" to which he suggests Yonge's Tractarianism is a throwback, he accuses her of mere religious formalism:

When it became evident that men had the power of getting at reality first-hand, whether in the facts of physical nature, or of intellectual research, or of religious experience, then that chasm began to open between the ecclesiastical and the natural-religious forms of civilisation which has never been understood at all by the ecclesiasticists, and which is even yet but imperfectly understood by their opponents. The prophecy of the former is, that if we give up the inviolability of the form, we lose all certainty of retaining our hold on the realities of religion, and must, sooner or later, drift into Atheism in belief, and mere anarchical individualism in society, each man doing what is right in his own eyes. (228)

Hutton rather patronizingly suggests that there is a divide in Yonge's fiction between her realism (her "truthful and inspiriting delineations of life from an affirmative and spiritual point of view") and the kind of typological significances which we have been exploring in this essay (which he classes as "a feeble reverence for damnatory theories and sacerdotal fictions") (230). From Yonge's point of view, however, as I hope to have shown, realism and typology cannot be separated in this way: typological significance is implicit in the form of the novel itself, as an attempt to generalize about human experience in language.

University of Central England

\section{NOTES}

1. The influence of Common Sense philosophy on Ruskin is described by Landow (1971, 154); the centrality of Common Sense philosophy to nineteenth-century ideas about the mind is set out by Rylance (44-45). Although Kant is often understood today as a philosophical realist, he was usually interpreted as a (Berkleyan or Humean) philosophical "idealist" in early British reception (Wellek $6,13)$ and his later nineteenth-century reception effectively assimilated him to Common Sense philosophy, which in any case was a significant influence on his position (Kuehn, passim). The role played by William Hamilton, one of the most prominent later nineteenth-century representatives of Common Sense philosophy, in promoting knowledge of Kantian philosophy in Britain, is symptomatic of this (Wellek 62).

2. The recurrent theme in The Heir of Redclyffe of Philip's utilitarian "logic" (which is eventually shown to be a pseudo-logic) may show the influence of Whately's Elements of Logic, cf. the scene where Philip is humiliated by Mr. Edmonstone's good-hearted, but illogical, reasons for forgiving him (Yonge 1997, 535).

3. Many elements in Mansfield Park, for instance, might be interpreted typologically, such as the significance attached to the play. A typological reading might not lead to a radically altered critical interpretation of the novel, but its possibility indicates the close relationship between potentially typological and apparently secular themes in her work (much the same could be said of a contemporary such as Edgeworth). In the context of Anglican natural theology and Paleyan utilitarianism which Austen inhabited, there is little friction between naturalistic modes of explanation and theological significance. It could be argued that the greater explicitness with which Yonge employs typological references is a response to the increased difficulty of combining typological elements with rationalistic perspectives by the $1850 \mathrm{~s}$ - indeed, the widening gap between rationalism and religion is explicitly thematized in The Heir of Redclyffe in the conflict between Philip and Guy. 
4. Levine refers to "induction" as constituting Thackeray's method (Levine 1981, 164); as a description of empiricist procedure this was first formulated by J. S. Mill in A System of Logic.

5. The continuing influence of Levine's secularizing claim that novelistic realism must necessarily be understood by readers as a representation of the consciousness of its author (Levine 1996, 239) can be seen in Byerly's recent argument that allusions to the arts of painting and music in early nineteenthcentury fiction serve the basic purpose of enhancing the "reality effect" of the represented world of the novel by means of contrast with their doubly fictive status (6-7). Byerly assumes the purpose of such allusions can only be to foster the novelistic illusion of realism because she shares Levine's view that novels cannot legitimately have any commitment to values beyond their own aesthetic world. Levine's arguments also form the basis for Lloyd's recent study; although Lloyd writes in a more theoretical idiom than Levine, his frequent admiring references to Levine (e.g., 123) show that he regards his work as an extension of Levine's arguments.

Watt cites 1930s Cambridge English as a formative influence on The Rise of the Novel (Watt 2000, 81). Interestingly in the context of this paper's argument about the influence of the Scottish Common Sense philosophical tradition on Yonge and the Tractarians, Watt, while claiming not to have any philosophical position, repeatedly claims the authority of "commonsense" for his attack on theoretical modes of criticism (cf. 76). This cannot be regarded as a merely naive gesture, as Watt's attack echoes many of the criticisms and turns of argument used by the founder of the Common Sense school, Reid in his critique of David Hume (cf. 83), a similarity which Frank, the editor of the special issue in which this lecture appears, recognizes when he describes this aspect of Watt's lecture as "Johnsonian" (x) it may be remembered that when Johnson famously kicked the stone to refute Berkleyan idealism, he did so in support of the Common Sense realism of Reid and Beattie (Boswell 1: 471). Simpson has commented on this affinity between recent critical attacks on "theory" and the Common Sense critique of Hume (2-4, cf. 49). Despite Watt's appeals to "commonsense," however, his fundamental allegiance to an empiricism of the type represented by Mill is shown by the table he includes to illustrate his conception of realism, in which "real life" unproblematically precedes novelistic representation in a way which suggests the Millian paradigm of "induction" (Watt 2000, 71).

McKeon's development of Watt's "close analogy between the epistemological premises of formal realism and those of "philosophical realism" (2) into a model where the novel is seen as a generic incarnation of "epistemological crisis" which is closely related to the "social crisis" represented by the decline in aristocratic conceptions of virtue (20-21), has implications which are very suggestive for The Heir of Redclyffe. Yonge's novel, as I argue in this paper, stages an epistemological crisis in Philip's refusal to be convinced of Guy's innocence, a crisis which is closely linked in the novel with the feudal authority exercised by Guy. Disappointingly, however, McKeon never refers to Hume in his account of the "extreme skepticism" by which "aristocratic ideology" is reasserted against bourgeois "naive empiricism" (21), despite the fact that this narrative describes Hume's outlook very accurately, so that it is difficult to link my analysis of The Heir of Redclyffe directly to his work. Gallagher's influential account of the way providential plots are problematized in the "condition of England" novel also has some points of contact with my arguments about The Heir of Redclyffe, although her analysis is vitiated by over-reliance on a supposed Romantic critique of industrialism and utilitarianism, a tradition which Connell has convincingly called into question. Gallagher accords a prominent position in her argument to James Martineau's rejection of his sister Harriet Martineau's brand of necessarian providentialism under the influence, she suggests, of American Transcendentalism (64), but James Martineau's later association with William Angus Knight (Mander and Sell 644) strongly suggests that Common Sense philosophy also played a role in this change of theological outlook. James Martineau's example suggests that Yonge's rejection of obvious forms of providentialism in her novels (Philip, for example, the "villain" of The Heir of Redclyffe, eventually inherits the estate) may be linked to the influence of Common Sense philosophy on her theological outlook.

The linking of realism to notions of linguistic performativity in Franklin (cf. 30) and Shaw (cf. xiii) represents the first serious challenge to the Wattsian paradigm of realism because, as Shaw 
remarks, it goes beyond the "single observer epistemology" implicit in Watts and Levine (71-72): for Shaw, his Habermasian focus on language as a communicative situation (35-36) necessarily places it beyond the reduction to a single consciousness which he finds typical of Levine and Watts (71-72). Interestingly, Shaw's identification of a "single observer epistemology" at work in Watts and Levine echoes some of Reid's criticisms of Hume (Reid 663-70), though this is not a reference Shaw makes; Shaw's emphasis on the communicative aspect of language also presents parallels with Reid's appeal to the communal standard of ordinary linguistic usage (Reid 222). Esterhammer has explored the connection between linguistic performativity and Common Sense philosophy. Since in Reid's philosophy, the possibility of linguistic intelligibility is closely linked to an argument for the existence of God, conceived as the ultimate source of language (Reid 664-65), it is possible to envisage a more immanent reading of The Heir of Redclyffe along the lines suggested by Shaw, which would find Philip's fault to consist in his failure to respect the intrinsic demands of the varying communicative situations which he inhabits, as opposed to the transcendent reading I suggest in this paper, in which Philip alienates himself from divinely inspired institutions. Shaw's reinterpretation (93-94) of Auerbach's category of "figural realism" (i.e., realism with a typological dimension) in terms of a "historicist metonymy" (103-04) which he sees as operative in nineteenth-century realism seems to point in this direction, in that he seeks to reinterpret the transcendence of the Figure as a collective immanence (it is interesting in this connection to note that Scott, whom Shaw credits with inventing the technique of "historicist metonymy," was one of Yonge's favorite novelists, which suggests that she might have interpreted this aspect of Scott's writing as indicating transcendence). The continuing intellectual validity of the appeal to transcendence which Yonge employs is, however, justified by the contemporary philosopher Alston, who uses Reid to argue against reduction of epistemological authority to a single source, whether it be consciousness or communicative situations $(162,235)$

The focus on performativity and theatricality in Shaw and Franklin is useful in relation to Yonge because it resists the reduction to individual consciousness which is fundamental to the approach of Levine, Byerly, and Lloyd. This is not to dispute the widely accepted critical view that "Western individualism is the recurring subject matter of the novel" (Richetti xiii) but to argue that differing ideological and epistemological constructions of individualism are at stake in The Heir of Redclyffe, as can be seen, for example in Yonge's emphasis on the way Philip's utilitarian discourse has stifled Laura's individuality. John makes a similar argument in relation to Dickens, suggesting that twentieth century criticism has typically found Dickens's novels flawed because of Dickens's own resistance to the developing bourgeois valorization of "inwardness" in character; Yonge's own resistance to the stress on "inwardness" can be seen in the way she portrays the characters of Philip and Laura in The Heir of Redclyffe. The prevalence of such psychologizing modes in twentieth-century criticism (following the modernist emphasis on "point of view" and "stream of consciousness") is presumably why Yonge's critical fortunes have been so poor since the nineteenth century. Recent critical calls for a rediscovery of affect in realist narrative, however, seem to point the way to a kind of interpretation which would avoid the modernistic reduction to individual consciousness which is characteristic of Levine and his followers. Tompkins pioneered this approach, and explicitly invokes typological significance in its support (134-36). She has been followed by Henning, whose use of Campbell's The Philosophy of Rhetoric as a base for examining mid nineteenth-century American women novelists brings her study very close intellectually to the present essay, since Campbell was an associate of Reid and other Common Sense philosophers - Henning herself doesn't make this connection, however. The importance of affect in Victorian realism has recently been explored in an impressive essay by Davis. Davis's remark that Dickens's A Christmas Carol offers "the impossible but also most needful thing: the opportunity to have feelings about your own feelings, vicariously, as if you were looking back at yourself as another person who was also you"(25) is relevant to Yonge's fictional mode, since this is exactly the perspective which religious insight allows Yonge's characters to achieve. Williams suggests how existing modes of critical interpretation might need to be revised in order to do justice to this kind of self-consciousness, proposing, instead of the prevailing critical tendency "to see plot as the 
content of narrative," a model in which "self-reflexive narrative moments" constitute narrative content (1998, 4-5). This reflexive dimension I would argue is continuously present in Yonge's narrative, as a consequence of the typological awareness she inherits from her Tractarian background.

6. Carlyle's indebtedness to Common Sense philosophy is described by Jessop; Ruskin's writings are an example of the influence of Common Sense philosophy on nineteenth-century aesthetics, which has been detailed in a French context by Manns.

7. Collins uses an indirect manner of presentation, but the argument is implicit in the way he juxtaposes his claim that the evidence for Christianity rests on essentially allegorical interpretations of the Old Testament with a lengthy quote from William Whiston to the effect that such allegorical interpretations of the Old Testament are absurd.

8. Prickett's recognition that Keble has a (philosophically) "realist," anti-subjective view of poetry is shown by his comment that Keble's attitude towards Nature is more akin to "the medieval and early Church's tradition of allegorical correspondences" (105), and his comment that Butler's Analogy of Religion reinforced the influence of Wordsworthian poetics on Keble (107-08). Keble's realist view of poetry would also seem to lie behind the avoidance of Coleridgean vocabulary which Prickett notes (117).

9. For recent discussions of the Common Sense school, see Woltersdorff and Jessop.

10. The Tractarians' general suspicion of the potential for "unreality" in ostentatious religious phraseology is reflected in the doctrine of "reserve" set out by Isaac Williams in "On Reserve in Communicating Religious Knowledge." The vocabulary of Biblical typology would have formed part of this religious phraseology, which was particularly associated with the Evangelicals. Yonge herself includes some implied criticism of the unreality of Evangelical religious discourse in her novel The Castle Builders (Yonge 1976, 84-86; ch. 6). The same novel, however, also makes it clear that mere immersion in daily incident is, in Yonge's terms, equally "unreal" (215; ch. 14).

11. There is evidence in Newman's philosophical notebooks that he read both Thomas Reid and Dugald Stewart, as is shown by Artz. Scottish Common Sense philosophy seems to have been an influence in general on the Oriel College "Noetics," of whom Newman was one; their leading light Edward Copleston refers to Stewart in his Inquiry into the Doctrines of Necessity and Predestination (cited in Whately $1830,410-11$ ).

12. This is the element in Yonge's writing to which Hutton seems to be responding when he accuses her of "ecclesiastical realism." Hutton appears to be using "realism" in a philosophical sense here, so that what he is protesting against is Yonge's assumption that Tractarian doctrine is identical with reality itself (224).

\section{WORKS CITED}

Abrams, M. H. The Mirror and the Lamp: Romantic Theory and the Critical Tradition. Oxford: Oxford UP, 1971.

Alston, William P. Perceiving God: the Epistemology of Religious Experience. Ithaca: Cornell UP, 1991. Anon, "Egotism." Monthly Packet 5 ns (1868): 517-18.

Artz, Johannes. "Newman as a Philosopher." International Philosophical Quarterly 16 (1976): 263-87.

Austen, Jane. Mansfield Park. Ed. and introd. Tony Tanner. Harmondsworth: Penguin, 1985.

Battiscombe, Georgina. Charlotte Mary Yonge: the Story of an Uneventful Life. London: Constable 1943.

B. L. K., "Imagination." Monthly Packet 1 ns (1866): 469-74, 472-73.

Borzello, Frances. "Pictures for the People." Victorian Artists and the City. Ed. Ira Bruce Nadel and F. S. Schwarzbach. New York: Pergamon P, 1980. 30-40.

Boswell, James. Boswell's Life of Johnson. Ed. G. Birkbeck Hill and L. F. Powell. 6 vols. Oxford: Clarendon $\mathrm{P}, 1934$. 
Brooke, Stopford. Theology in the English Poets: Cowper, Coleridge, Wordsworth and Burns. London: Dent and Dutton, n.d.

Brooks, Chris. Signs for the Times: Symbolic Realism in the Mid-Victorian World. London: Allan, 1984.

Budge, Gavin. "Poverty and the Picture Gallery: The Whitechapel Exhibitions and the Social Project of Ruskinian Aesthetics." Visual Culture in Britain 1.2 (2000): 43-56.

Burke, Edmund. A Philosophical Inquiry into the Origin of Our Ideas of the Sublime and Beautiful. Vol. 1.The Writings and Speeches of Edmund Burke. Ed. T. O. McLoughlin and J. T. Boulton. Oxford: Clarendon P, 1997.

Butler, Joseph. The Analogy of Religion, in The Works of Joseph Butler. Ed. W. E. Gladstone. 2 vols. Oxford: Clarendon P, 1896.

Byerly, Allison. Realism, Representation, and the Arts in Nineteenth-Century Literature. Cambridge: Cambridge UP, 1997.

Campbell, George. The Philosophy of Rhetoric. 1776. Carbondale: Southern Illinois UP, 1988.

Coleridge, S. T. Biographia Literaria. Ed. James Engell and W. Jackson Bate. 2 vols. London and Princeton: Routledge \& Kegan Paul and Princeton UP, 1983.

Collins, Anthony. A Discourse of the Grounds and Reasons of the Christian Religion. London: 1724.

Connell, Philip. Romanticism, Economics and the Question of "Culture." Oxford: Oxford UP, 2001.

Davis, Philip. "Victorian Realist Prose and Sentimentality." Rereading Victorian Fiction. Ed. Alice Jenkins and Juliet John. Houndmills: Macmillan, 2000. 13-28.

Eigner, Edwin M. The Metaphysical Novel in England and America: Dickens, Bulwer, Melville, and Hawthorne. Berkeley: U of California P, 1978.

Ellis, Sarah. The Women of England. London \& New York: London Printing and Publishing, 1839.

Esterhammer, Angela. The Romantic Performative: Language and Action in British and German Romanticism. Stanford: Stanford UP, 2000.

Fish, Stanley. "Interpreting the Variorum." Reader-Response Criticism: from Formalism To PostStructuralism. Ed. Jane P. Tompkins. Baltimore: Johns Hopkins UP, 1980. 164-84.

Frank, Joseph. "Introduction." Stanford Humanities Review 8.1 (2000): i-xiv.

Franklin, J. Jeffrey. Serious Play: the Cultural Form of the Nineteenth Century Realist Novel. Philadelphia: U of Pennsylvania P, 1999.

Fraser, Hilary. Beauty and Belief: Aesthetics and Religion in Victorian Literature. Cambridge: Cambridge UP, 1986.

Gallagher, Catherine. The Industrial Reformation of English Fiction: Social Discourse and Narrative Form 1832-1867. Chicago: U of Chicago P, 1985.

Green-Lewis, Jennifer. Framing the Victorians: Photography and the Culture of Realism. Ithaca: Cornell UP, 1996.

Henning, Martha L. Beyond Understanding: Appeals to the Imagination, Passions, and Will in MidNineteenth Century American Women's Fiction. New York: Lang, 1996.

Horne, Thomas Hartwell. An Introduction to the Critical Study and Knowledge of the Holy Scriptures. 4th ed. London: Cadell, 1818.

Hutton, R. H. "Ethical and Dogmatic Fiction: Miss Yonge." National Review 12 (1861): 211-30.

Jessop, Ralph. Carlyle and Scottish Thought. Basingstoke: Macmillan, 1997.

John, Juliet. Dickens's Villains: Melodrama, Character, Popular Culture. Oxford UP, 2001.

Keble, John. Keble's Lectures on Poetry 1832-1841. Trans. Edward Kershaw Francis. 2 vols. Oxford: Clarendon P, 1912.

. "Morning." Christian Year. London: Dent and Dutton, 1914. 5.

. "On the Mysticism Attributed to the Early Fathers of the Church." Vol. 6, Tract no. 89. Tracts for the Times. 6 vols. London: Rivington, 1839-43.

— . "Sacred Poetry." 1814. Occasional Papers and Reviews. Ed. E. B. Pusey. Oxford: Parker, 1877. 81-07.

Korshin, Paul J. Typologies in England 1650-1820. Princeton: Princeton UP, 1982. 
Kuehn, Manfred. Scottish Common Sense in Germany, 1768-1800. Montreal: McGill-Queen's UP, 1987. Landow, George P. The Aesthetic and Critical Theories of John Ruskin. Princeton: Princeton UP, 1971. . Victorian Types, Victorian Shadows: Biblical Typology in Victorian Literature, Art and Thought. London: Routledge and Kegan Paul, 1980.

Levine, George. "Realism Reconsidered." Essentials of the Theory of Fiction. Ed. Michael J.Hoffman and Patrick D. Murphy. 2nd ed. London: Leicester UP, 1996. 234-45.

- The Realistic Imagination: English Fiction from Frankenstein to Lady Chatterley. Chicago: UP, 1981.

Lloyd, Tom. Crises of Realism: Representing Experience in the British Novel 1816-1910. Lewisburg: Bucknell UP, 1997.

Locke, John. An Essay Concerning Human Understanding. Ed. P. H. Nidditch. Oxford: Clarendon P, 1975.

Lowth, Robert. Lectures on the Sacred Poetry of the Hebrews. 2 vols. Fac. Reprint of 1st ed. [London, 1837] Robert Lowth, 1710-87: the Major Works. 6 vols. London: Routledge/Themmes, 1995.

Magee, William. Discourses and Dissertations on the Scriptural Doctrines of Atonement and Sacrifice. London: Bohn, 1852.

Mander, W. J., and Alan P. Sell, eds. The Dictionary of Nineteenth Century British Philosophers. Bristol: Thoemmes P, 2002.

Manns, James W. Reid and his French Disciples: Leiden: Brill, 1994.

[Mansel, H. J.] "Sensation Novels.” Quarterly Review 113 (April 1863): 481-514.

McKeon, Michael. The Origins of the English Novel 1600-1740. Baltimore and London: Johns Hopkins UP, 1987.

Middleton, R. D. Newman at Oxford: His Religious Development. Oxford: Oxford UP, 1950.

Mill, John Stuart. A System of Logic Ratiocinative and Inductive: Being a Connected View of the Principles of Evidence and the Methods of Scientific Investigation. Ed. J. M. Robson and R. F. McRae. Toronto: Toronto UP, 1973.

Newman, John Henry. [Sermons Preached Before the University of Oxford. 1843.] Newman's University Sermons. Ed. D. M. MacKinnon and J. D. Holmes: SPCK 1970.

Packe, Michael St. John. The Life of John Stuart Mill. London: Secker and Warburg 1954.

Prickett, Stephen. Romanticism and Religion: the Tradition of Coleridge and Wordsworth in the Victorian Church. Cambridge: Cambridge UP, 1976.

Reid, Thomas. Works. Ed. William Hamilton. 7th ed. Edinburgh: Maclachlan and Stewart, 1872.

Richetti, John, ed. The Columbia History of the Novel. Columbia: Columbia UP, 1994.

Ruskin, John. Works. Ed. E. T. Cook and Alexander Wedderburn. 39 vols. London: Allen, 1903-12.

Rylance, Rick. Victorian Psychology and British Culture 1850-1880. Oxford: Oxford UP, 2000.

Sandbach-Dahlström, Catherine. Be Good Sweet Maid: Charlotte Yonge's Domestic Fiction: A Study in Dogmatic Purpose and Fictional Form. Stockholm: Almqvist and Wiksell International, 1984.

Shaw, Harry E. Narrating Reality: Austen, Scott, Eliot. Ithaca: Cornell UP, 1999.

Simpson, David. Romanticism, Nationalism and the Revolt Against Theory. Chicago: U of Chicago P, 1993.

[Stephens, F. G.] William Holman Hunt and his Works: a Memoir of the Artist's Life with Description of his Pictures. London: Nisbet, 1860.

Sturrock, June. "Heaven and Home": Charlotte M. Yonge's Domestic Fiction and the Victorian Debate over Women. Victoria: English Literary Studies, U of Victoria, 1995.

Süssman, Herbert L. Fact into Figure: Typology in Carlyle, Ruskin, and the Pre-Raphaelite Brotherhood. Columbus: Ohio State UP, 1979.

Tennyson, G. B. “'So Careful of the Type?' - Victorian Biblical Typology: Sources and Applications.” Essays and Studies 37 (1984): 31-45.

Thackeray, William Makepeace. Vanity Fair. Ed. Jim Stewart. Harmondsworth: Penguin 1968.

Tillotson, Kathleen. "Charlotte Yonge as a Critic of Literature." A Chaplet for Charlotte Yonge. Ed. Georgina Battiscombe and Marghanita Laski. London: Cresset 1965, 56-70.

Toland, John. Christianity not Mysterious. Dublin: Lilliput P, 1997. 
Tompkins, Jane. Sensational Designs: the Cultural Work of American Fiction 1790-1860. New York: Oxford UP, 1985.

Watt, Ian. "Realism and Modern Criticism of the Novel." Stanford Humanities Review 8.1 (2000): 70-85. . The Rise of the Novel. London: Chatto and Windus, 1957.

Wellek, René. Immanuel Kant in England 1783-1838. Princeton: Princeton UP, 1931.

Whately, Richard. Elements of Logic. 9th edition. London: Longmans, Green, 1878. . Elements of Rhetoric. Oxford and London: Murray and Parker, 1830.

Williams, Jeffrey. Theory and the Novel: Narrative Reflexivity in the British Tradition. Cambridge: Cambridge UP, 1998.

Williams, Isaac. "On Reserve in Communicating Religious Knowledge." Vols. 4 and 5, Tracts nos. 80 and 87. Tracts for the Times. 6 vols. London: Rivington, 1839-43.

Wolff, Robert Lee. Gains and Losses: Novels of Faith and Doubt in Victorian England. New York: Garland, 1977.

Woltersdorff, Nicholas. Thomas Reid and the Story of Epistemology. Cambridge: Cambridge UP, 2000.

Yonge, Charlotte M. Abbeychurch. Facsimile reprint of London 1844 ed. New York: Garland, 1976,

_. "Authorship." A Chaplet for Charlotte Yonge. Ed. Georgina Battiscombe and Marghanita Laski. London: Cresset, 1965. 185-92.

- The Castle Builders. New York: Garland 1976. Facsimile of London, 1854.

The Heir of Redclyffe. Ed. Barbara Dennis. Oxford: Oxford UP, 1997.

The Pillars of the House. 2 vols. London: Macmillan, 1901.

. The Trial. London and New York: 1891. 